Fish and Fisheries

September 2010, Volume 11, Issue 3, pages 289-306

http://dx.doi.org/10.1111/j.1467-2979.2010.00362.x

(c) 2010 Blackwell Publishing Ltd.

The definitive version is available at http://onlinelibrary.wiley.com/

\title{
The duration of migration of Atlantic Anguilla larvae
}

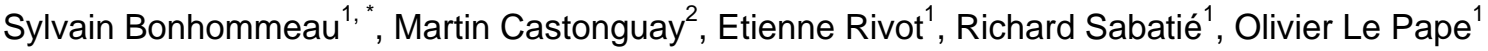

${ }^{1}$ AGROCAMPUS OUEST, UMR 985 INRA-AGROCAMPUS OUEST Ecologie et Santé des Ecosystèmes, Laboratoire Ecologie Halieutique, 65 rue de St-Brieuc, CS 84 215, 35042 Rennes cedex, France

${ }^{2}$ Pêches et Océans Canada, Institut Maurice-Lamontagne, 850 Route de la Mer, C.P. 1000, Mont-Joli, Québec, Canada G5H $3 Z 4$

*: Corresponding author : Sylvain Bonhommeau, Tel.: +33499573266 Fax: +33499573295, email address :

sylvain.bonhommeau@ifremer.fr

\begin{abstract}
:
Oceanic larvae of the European (Anguilla anguilla) and American (A. rostrata) eels have to cross the Atlantic Ocean from the Sargasso Sea to European or North American coasts before entering continental habitats. In some European rivers, eel recruitment is now $<1 \%$ of levels in the 1980 s. A better understanding of the effects of anthropogenic pressures and environmental fluctuations on eel larvae and subsequent recruitment is a prerequisite to build efficient management plans. The present paper provides insight into the critical oceanic phase of the eel life cycle with a focus on the duration of the larval migration whose estimates varies between 7 months and more than 2 years in both species. Does this range correspond to a natural variability in larval duration or does it stem from methodological artefacts? We first review the different methods used to estimate the duration of larval migration and critically describe their possible sources of misinterpretation. We then evaluate the consistency of these methods with the current knowledge about the ecology and physiology of eel larvae and the physical oceanography. While a moderate discrepancy in migration duration was found between methods for the American eel, the discrepancy was large in the European eel. In this species, otolith microstructure studies indicated migration durations between 7 and 9 months, while other methods pointed to durations of about 2 years. We show that estimates in favour of a long migration duration seem more robust to methodological caveats than methods estimating short durations of migration.
\end{abstract}

Keywords: Anguilla, leptocephali, migration, North Atlantic, Sargasso Sea; Lagrangian modelling, otoliths 


\section{Introduction}

The main features of the life cycle of Atlantic eels (the European eel, Anguilla anguilla and the American eel, A. rostrata) are now well established. Over the last 15 years, nearly one paper a day has been published on eels, involving a large spectrum of disciplines: 5628 papers as shown by a search of the key words Anguilla and eel in the ISI Web of Knowledge. Atlantic eels are catadromous fish that perform one of the longest seaward migrations, with the European eel travelling more than $6,000 \mathrm{~km}$ across the Atlantic Ocean. Before the spawning migration, yellow eels that live in rivers, lagoons or coastal waters mature into silver eels. Silver eels then cross the Atlantic Ocean to spawn in the southwestern Sargasso Sea. Conveyed by warm currents, eel larvae (leptocephali) drift from the spawning area to settle either in fresh, brackish, or salt waters of African and European shelves, from Northern Africa to the Polar Circle for the European eel or on American and Canadian shelves for the American eel (Schmidt 1923).

Despite tremendous research efforts devoted to unravel the life history of the eel, crucial aspects still remain unknown. Improving our knowledge of the eel's life history is a prerequisite to building efficient management plans for this endangered species. Efforts to understand and manage eels in a sustainable way become all the more urgent in the light of the current pronounced decline in eel populations worldwide (Anonymous 2003). In some European rivers, eel recruitment is now less than $1 \%$ of levels in the 1980 s, and the European eel was recently listed in Appendix II of the Convention on International Trade in Endangered Species of Wild Fauna and Flora (CITES 2007).

Most of the gaps in knowledge concern the oceanic life stages of eels. An overview of the historical research on the oceanic phase of eels illustrates the difficulty in improving our knowledge on this part of the life cycle, mostly because of the difficulty of observing eels during their marine life stages.

Until the work of Grassi (1896), eels were thought to live in freshwater and the larvae were considered to be another species, Leptocephalus brevirostris (Kaup 1856). The discovery of the metamorphosis of the leptocephalus into a glass eel by Grassi (1896) had far-reaching repercussions in terms of management since eels fished in freshwater have not yet had the chance to reproduce. To initiate research on eel biology and find eel spawners and larvae, Johannes Schmidt undertook travels and surveys around the Atlantic Ocean and the Mediterranean Sea and collected more than 10,000 European eel larvae and 2,400 American eel larvae over the whole North Atlantic Ocean (Schmidt 1927, 1935) and in the Mediterranean Sea (Strubberg 1923) over a period of 25 years. The overlapping breeding places of the two Atlantic eel species were discovered and identified in the Sargasso Sea. In one of his letters, Johannes Schmidt described his advances in locating the eel spawning area during his numerous expeditions in the Atlantic Ocean: "I think I am now able after so many years' work, to chart out the spawning places of the European eel (Anguilla vulgaris)" (Smith 1921). Nearly a century later, thanks to the investigations of several scientists in the Sargasso Sea (e.g., Tesch et al. 1979; McCleave et al. 1987), some aspects of the oceanic biology of Atlantic eels are more precisely established than Schmidt's findings (Schmidt 1922, 1923). During the 50 years following the last of Schmidt's cruises, expeditions searching for small larvae and spawning eels have been carried out to refine Schmidt's results (e.g., Vladykov 1964; Valdykov and March 1975; Schoth and Tesch 1983; Wippelhauser et al. 1985; Castonguay and McCleave 1987; McCleave et al. 1987; Kleckner and McCleave 1988; Tesch and Wegner 1989). On the basis of this new knowledge, a more accurate location of spawning areas and timing of spawning have been described. Results have confirmed the spatial overlap of spawning areas between the two species. Spawning seasons also overlap as they mainly occur from March to June for the European eel and from February to April for the American eel (McCleave et al. 1987; McCleave and Kleckner 1987). Spawning occurs within and south of thermal fronts separating the northern from the southern Sargasso Sea (Kleckner and McCleave 1988).

Given the number of mysteries remaining about the oceanic phase of eels, one of the biggest "eel challenges" will be to improve our knowledge on the oceanic larval stages. As for most 
fish species, the larval stage is one of the most important sources of eel mortality $(\mathrm{Hjort}$ 1914). The gains will not only be for pure ecology. There is also an urgent need to improve our understanding of eel recruitment for management and conservation purposes.

In keeping with the above challenge, the duration of larval migrations is fundamental to population dynamics. It determines the timing of recruitment but also fixes the recruitment intensity because larval mortality strongly depends upon the duration of migration. This is also linked to the oceanic trajectories of larvae which determine the spatial pattern of recruitment on continental shelves. It is noteworthy that the migration duration remains controversial. In the words of Grassi (1896) mentioning the migration duration of European eel larvae: "What length of time this development requires is very difficult to establish". This statement is still true today. Different methods have led to different estimates of the duration of migration ranging from 7 months to more than 6 years for the European eel and from 4 months to 2 years for the American eel. None of these estimations have been validated so far. The lack of consensus is particularly visible and critical when trying to understand recruitment variability. Since eel total larval abundance has never been estimated, the only available recruitment data are the abundance or recruitment indices of glass eels. Migration duration has strong implications for the understanding of recruitment fluctuations. Because environmental factors may influence recruitment during early life stages, time lags have to be accounted for to relate environmental series to coastal glass eel recruitment series. For example, Friedland et al. (2007) used a 1-year lag for European eel, but Knights (2003) and Bonhommeau et al. (2008a and b) used a delay of 2.5-3 years. These studies did not use the same migration duration even though they were based on the same body of literature (e.g., Schmidt 1923; Lecomte-Finiger 1994a; Tesch 2003). Such discrepancies in the estimation of migration duration remain unresolved (McCleave 2008).

In this paper, we review the available literature on the oceanic migration of Atlantic eel larvae, with a special emphasis on the migration duration. Recent reviews of Lecomte-Finiger (2003), Van Ginneken and Maes (2005) and McCleave (2008) provide interesting synthesis, but none of them focuses on the duration of the migration of eel larvae, although this is one of the most critical features of the oceanic larval stage. This paper first aims at reviewing the results of the different methods used to determine the duration of migration of Atlantic eels (i.e. cohorts analysis, analysis of macrostructure and microstructure of otoliths, and ocean general circulation models) as well as pointing out the potential methodological caveats inherent to each method which may be sources of bias. We then provide a synthesis to determine the most credible hypothesis when accounting for eel larval biology and physiology as well as physical oceanography. Lastly, we propose research avenues that could lead to the resolution of this issue.

\section{Estimation of the duration of migration}

\subsection{Cohort and growth curve analysis (in situ sampling)}

\subsubsection{Results}

The spatial (eastward) gradient in larval length observed at different locations was mapped by Schmidt (1923) and refined by Tucker (1959), Boëtius and Harding (1985), and McCleave et al. (1987). The duration of eel larval migration was first assessed by plotting the monthly leptocephali lengths for each month sampled (Schmidt 1922), thus establishing growth curves based on the eastward change in size of $A$. anguilla. Schmidt (1922) evaluated that the European larvae take on average two years to grow and attain the size of about $70-80$ $\mathrm{mm}$, and added that nearly three years elapsed before the metamorphosis into glass eel is completed. The length classes were then interpreted as three year classes that are simultaneously present in early summer in the Atlantic Ocean: the youngest in the western, 
the next in the central, and the oldest in the eastern Atlantic Ocean (Schmidt 1922). The reanalysis of Schmidt's sampling stations by Boëtius and Harding (1985) provided some insights into the duration of migration. They separated leptocephali in annual age groups and found many stations where "0-group" and "I-group" larvae occur together, but few where "Igroup" and "Il-group" can be found together. Where they did occur together it was mainly in the western Mediterranean. The "I-group" larvae could be found throughout the year over the entire North Atlantic. Boëtius and Harding (1985) argued that some individuals can grow continuously from $10 \mathrm{~mm}$ to $60 \mathrm{~mm}$ or more in a single year, and can reach a length of 80 mm within 12-15 months. Regarding the American eel larvae, Schmidt (1922) concluded that leptocephali grow more rapidly and can complete full development from egg to elver in about a year.

In summary, the extensive pioneer work of Schmidt and subsequent expeditions based on larval sampling proposed that migration lasts for 1 year for the American eel and 2-3 years for the European eel.

\subsubsection{Possible sources of misinterpretation}

Results from cohort analysis remain questionable because the analysis is based on length of eel larvae and not on age. The growth curve drawn by Schmidt (1922) stems from the different size groups he identified. In the same month (June 1905), Schmidt found three different size classes of European eel larvae in the Atlantic Ocean: a 7-37 mm size class centred in the western Atlantic (0-Group), a 40-70 mm class in the central Atlantic (I-Group), and a 60-88 mm class off Europe (II-Group). He also found a III-Group, representing recently metamorphosed glass eels. This simultaneous presence of three size-classes of larvae in the North Atlantic led him to conclude that larvae take on average 2 years to grow from the 0-Group to the II-Group and that nearly 3 years elapse before the metamorphosis is completed. Since this hypothetical age-length relationship has never been validated and relies on indirect empirical evidence, Schmidt's assertion remains questionable. Moreover, Tesch et al. (1985) found a geographic gradient in the length of larvae with smaller larvae in southern Europe and larger in northern Europe, as well as several age classes at the same locations, indicating that different size classes may be mixed during oceanic transport.

Accordingly, Boëtius and Harding (1985) re-examined growth curves derived from Schmidt's investigations and found a much higher growth rate for European eel leptocephali and a duration of migration of around 1.5 years. However, larvae longer than $60 \mathrm{~mm}$ have been found close to the spawning area, suggesting their recirculation within the subtropical gyre surrounding the Sargasso Sea (Boëtius and Harding 1985). The fate of these larvae is uncertain.

\subsection{Interpretation of the macrostructure of eel otoliths}

\subsubsection{Results}

The ability to tell the age of a fish accurately from its otoliths, scales, fin rays or other structures is one of the most useful features in fish biology and fishery science. The interpretation of otolith macrostructure has long been accepted as the most suitable tool for age determination in eels (Moriarty 1973). Otolith macrostructure has been extensively used to investigate the duration of the larval oceanic stage. Liew (1974) found a pattern of summer and winter growth, suggesting that American eel elvers may have spent two years at sea. van Utrecht and Holleboom (1985) compared the otoliths of European eel larvae collected in the mid Atlantic and along the continental slope off the Portuguese coast with the otoliths of glass eels collected just before entering fresh water along the Dutch and French coasts. The majority of leptocephali caught in the mid-Atlantic had three complete growth zones while 
those from the continental slope had four complete growth signatures. van Utrecht and Holleboom (1985) assumed that these growth zones were annual increments, implying that the glass eels arriving along the Dutch and French coasts vary between 2 and 6 years of age.

In summary, the interpretation of otolith macrostructures led to estimates of the migration lasting for 2 years for the American eel and between 2 and 6 years for the European eel, which is longer than results from cohort analysis.

\subsubsection{Possible sources of misinterpretation}

The interpretation of the otolith macrostructure is uncertain. Indeed, no distinct correlation was found between the occurrence or absence of growth zones and the onset of summer or winter with corresponding growth or absence of growth. In other words, eel otoliths include false annuli that are difficult to distinguish from true ones, making annual age determination uncertain (Dahl 1967; Liew 1974; Deelder 1976; Moriarty 1983). These structures were called "supernumerary zones" by Deelder (1976). It was also shown by Casselman (1982) that the surface of sections that appeared to be uniformly translucent may contain calcium zones even though an optical zone was not apparent.

An experiment led by Moriarty and Steinmetz (1979) compared different age assessment methods. An original aspect of this work was to distribute the same eel otoliths to five experienced readers to compare their age determinations. Differences between age determinations for the same eel by different readers were in many cases over $100 \%$. Svedäng et al. (1998) found the same discrepancies both between readers and between eel origins, illustrating the need for training and reference collections. An inter-calibration exercise conducted recently showed that a lot of variability in age determinations by different readers (ICES 2009). Different methods have been proposed to improve annual age determination in eels (Deelder 1981; Berg 1985; Véró et al. 1986; Dekker 1987; Vøllestad et al. 1987), such as polishing otoliths (Wiedemann Smith 1968) or densitometry (Deelder 1976). However, the success of these methods remains case-specific (Michaud et al. 1988; Vøllestad and Næsje 1988). All these results indicate that annual age determination in eels remains subjective.

\subsection{Interpretation of the microstructure of eel otoliths}

\subsubsection{Results}

Pannella (1971) demonstrated the presence of daily growth increments in otoliths of marine fish. In the late 1980s, numerous studies concentrated on the analysis of microstructure of eel otoliths, providing a wide range of information about larval life history.

For the Japanese eel, it has been shown that daily increments are deposited in sagittae at larval and elver stages, and the back-calculated age of Japanese eel larvae has been estimated to vary from 4 to 6 months (Tsukamoto and Umezawa 1988; Tsukamoto 1989; Tsukamoto et al. 1988, 1989; Umezawa and Tsukamoto 1989). It was further demonstrated (Martin 1995; Cieri and McCleave, 2001) that increments are deposited daily in the American eel at the glass eel stage. Powles et al. (2006) also demonstrated daily increment formation during metamorphosis in the speckled worm eel (Myrophis punctatus).

Although it has not been demonstrated for European and American eel leptocephali, the assumption of daily increments was used by several authors to back-calculate larval migration duration. Relying on this assumption, the otolith microstructure analysis of European and American eel larvae supported a short migration duration hypothesis, which provided a completely different interpretation of the oceanic migration of larvae from the hypothesis supported hitherto by the analysis of cohorts and otolith macrostructure. 
Castonguay (1987) calculated a faster growth rate in leptocephali based on microstructure increments compared to what had been calculated from previous approaches (Boëtius and Harding 1985; Wippelhauser et al. 1985). Estimates made using 423 glass eels from the Netherlands to Morocco gave a duration of migration of between 216 and 276 days or about 7 to 9 months, for glass eels caught in Spain and the UK, respectively (Lecomte-Finiger 1992, 1994a). Arai et al. (2000) found similar duration of migration, lasting for 7-9 months for $A$. anguilla and 6-8 months for $A$. rostrata. This was reconsidered by Wang and Tzeng (2000) when analyzing the otolith microstructure of 479 elvers of American and 440 European eels. They found the age of American eel elvers to range between 7 and 9 months, which included 55 days for metamorphosis into glass eels, as previously found by Wang and Tzeng (1998), and the age of European eel elvers to vary between 14 and 16 months including 98 days for metamorphosis.

\subsubsection{Possible sources of misinterpretation}

Annual age determination of eels by interpreting macrostructure of otoliths is uncertain but did not yield results contradictory to Schmidt's (1922) interpretation of larval migration. In contrast, results based on daily increments conflicted with all other estimates of migration duration (e.g., Lecomte-Finiger 1992; Arai et al. 2000). A debate on the validity of the otolith method in larval eels ensued. This debate is not restricted to the eel case. Although there is no reason to doubt the apparent universality of daily increment formation in young fish under adequate growth conditions (Campana and Neilson 1985), there are a number of reported exceptions, all from temperate pelagic larvae, which indicate that other mechanisms could conceivably complicate or invalidate age interpretations derived from otolith microstructure (Campana et al. 1987). In the case of eels, several authors pointed out that the interpretation of otolith microstructure may suffer from several drawbacks, in particular the lack of validation of daily rings and the difficult interpretation of the diffusive zone.

\section{Possible non-daily increments in eel larvae?}

The microstructure of eel otoliths has been interpreted as daily increments, but several (possibly cumulative) hypotheses may explain an apparent increment formation less frequent than daily. The growth rate limitation hypothesis of Geffen (1982) has been cited as being consistent with the results of a number of studies (Bergstad 1984; McGurk 1984). Nondaily increment formation has been observed in a variety of fish species with slow-growing phases (Methot and Kramer 1979; Laroche et al. 1982; Bergstad 1984; Campana 1984).

Limits of optical resolution may also prevent the accurate interpretation of otolith microstructure (Geffen 1992). Daily increments could be formed in the eel otolith, but below the resolution limit of either light or scanning electron microscopy (SEM), which may be of little help in otoliths where increments are extremely narrow. In the case of SEM, it could be that the chemical contrast between the incremental and discontinuous zones of a given daily increment is too weak to allow etching. The hypothesis of inadequate resolution was first presented when it was noted that narrow daily increments could only be seen after adequate otolith preparation (Campana 1984). It is thus theoretically possible for daily increments to form below the resolution limit of microscopy, leading to the situation where the increment formation rate appears to be lower than the true daily rate (Campana et al. 1987). These authors proposed two criteria to identify the potential existence of such a bias. The first one is where increment width is less than $1 \mu \mathrm{m}$. The second criterion concerns otoliths where increment width appears to increase in proximity to the nucleus. It is worth pointing out that otoliths of glass eels fit the two warning criteria described by Campana et al. (1987): the mean growth rate of the otoliths is $0.605 \pm 0.060 \mu \mathrm{m} \cdot \mathrm{d}^{-1}$ and the 50 first increments are wider than later increments (Lecomte-Finiger 1992, 1994b). Regions likely exist in the eel otolith where the daily growth has slowed to the point where discrete increments are not visible, and those ageing eels are unconsciously interpolating through those regions (S. E. 
Campana, Bedford Institute of Oceanography, Halifax, Nova Scotia, Canada, personal communication).

Leptocephali may have such a low metabolic rate that otolith increments are not deposited daily, or are deposited daily but are too narrow to be observable using either light microscopy or scanning electronic microscopy. For instance, Umezawa and Tsukamoto (1991) noted a decline in ring deposition after 5 days in unfed elvers or in elvers held at low temperatures. Ring deposition may depend on nutritional conditions and temperature. This has been recently described for Japanese glass eels and elvers by Fukuda et al. (2009) who reported that no otolith growth occurred at 5 and $10^{\circ} \mathrm{C}$ and that growth slowed down in unfed individuals. In contrast to the nutrient-rich near shore waters, the open ocean is much poorer, gradually becoming less productive with increasing distance from the continent (e.g., Behrenfeld et al. 2006; Raven et al. 2007). Atlantic eel larvae experience low productive tropical oceanic areas (Polovina et al., 2008). While the European and American eel migration pathway is much less productive and could lead to an apparent non-daily increment formation of otoliths, the Japanese eel larval migration routes cross relatively high food conditions. This may explain why the daily increment hypothesis is less controversial than for the European eel. Indeed, in the Pacific, the specific location of Japanese eel spawning areas near seamounts may be linked to their functional role in nutrient transport. Seamounts have been shown to induce perturbations in nutrient distributions, leading to enhanced upward transport of nutrients into the euphotic zone (Furuya et al. 1995) and an elevated amount of chlorophyll $a$ and related biological productivity downstream.

\section{The interpretation of the diffusive zone remains contentious}

Another contentious issue concerns the diffusive, so-called "metamorphic" zone. The diffusive zone is interpreted as the metamorphosis stage of leptocephali. Since no narrow circumscribed rings are visible, the diffusive zone may therefore prevent an accurate estimation of the duration of migration (Correia et al. 2002, 2004, 2006). The interpretation of the diffusive zone was reconsidered by Antunes and Tesch (1997) and McCleave et al (1998) who raised the question "can growth rate estimated from the translucent zone be extrapolated to the diffusive zone?". It was suggested by Antunes and Tesch (1997) that part of the diffuse zone may have been formed during a larval phase of retarded growth, during which no formation of daily rings takes place. The low metabolic rate and uncertainty in the mode of nutrition of leptocephali lends support to such an interpretation (McCleave et al. 1998).

Another bias may stem from otolith resorption during metamorphosis. Cieri and McCleave (2000) emphasized the specific remobilization of both strontium and calcium needed during metamorphosis, which may imply not only the resorption of teeth (Hulet and Robins 1989), as observed in another Anguilliform (Ariosoma balearicum), but also resorption of otoliths. However, this possible mechanism remains highly speculative, as there is no evidence of otolith resorption in any fish species (Campana and Neilson 1985).

In conclusion, the microstructure analyses have been shown to be accurate in many fish species and even in some species of Anguilla (e.g., Tsukamoto et al. 1988; Kuroki et al. 2006), but our review indicates that many uncertainties remain about daily ageing for American and European eels.

\subsection{Ocean circulation models}

\subsubsection{Results}

Schmidt (1923) noticed that "[...] the distribution of the eels in the Atlantic area distinctly coincides with the periphery of the great anti-cyclonic circulation of water-masses in the 
North Atlantic". This suggested to Schmidt that passive drift may enhance transport of larvae to the North American and European shelves. First estimates of duration of migration were made from several bottle experiments carried out by Winge (1923), Prince Albert of Monaco (1932), Pouchet (1939), and Hermann and Thomsen (1946). These experiments fitted with Schmidt's estimate of 2.5-3 years (Schmidt 1922, 1923; Harden Jones 1968). It is nonetheless quite difficult to compare floating objects that are both current- and wind-driven to leptocephali that are mainly found at depths between 50 and $300 \mathrm{~m}$ (Tesch 1980; Castonguay and McCleave 1987). To get closer to the conditions encountered by leptocephali, Harden Jones (1968) used observations of surface current speeds collected by British merchant and naval ships to plot the drift of leptocephali. He found that passive drift would lead larvae to arrive over the continental shelf southwest of Ireland about 2 years and 9 months after hatching in the Sargasso Sea. Although this simulation does not account for the deeper position of eel larvae, it gives an idea of the duration of a passive drift.

A first numerical model of surface currents was developed by Power and McCleave (1983) to model the drift of particles released in the spawning areas of American and European eels. Current fields used for this model were derived from drift of ships obtained from the U.S. National Oceanographic Data Center with a $1^{\circ}$ latitude-longitude grid. Model results suggest that larvae drift slowly from the spawning area to the northwest and form a persistent accumulation northeast of the Bahamas. The gradual transport of "0-group" larvae into the Gulf Stream suggested by this model was consistent with in situ data (Kleckner and McCleave 1985). This model simulation was stopped after 270 days because it was assumed that by then, leptocephali may metamorphose and reach fresh waters by means other than passive drift. The model did not estimate the duration of migration, but it suggested that leptocephali of American and European eels gradually drift passively into the Gulf Stream about 6 months after hatching. McCleave and Kleckner (1987) tried to validate the predictions obtained by simulations with in situ observations to determine the distribution of American and European eel larvae in the western Sargasso Sea in summer and fall. Two cruises were carried out in 1984 with transects running from the Gulf Stream southeast into the Sargasso Sea. Their results confirmed the general conclusion from the simulations that leptocephali are not rapidly swept from the Sargasso Sea into the Gulf Stream and that substantial concentrations of leptocephali are retained in the Sargasso Sea for several months following hatching.

Recent advances in global oceanic current simulation improved the modelling of particle drift and provided insight into the migration of larvae. Using Lagrangian models, Kimura et al. (1999) and Kim et al. (2007) explained the timing of arrival and the distribution of Japanese eel larvae in South Asia. Concerning the duration of migration, they confirmed the 4-6 month duration by a passive drift from the seamounts near the Mariana Islands to the coasts of Taiwan and Japan as proposed by otolith studies (e.g., Tsukamoto et al. 1989). Using the same method, Kettle and Haines (2006) reproduced the main pattern of the migration of European eel larvae. This study concluded that the duration of migration is 2 years for the European eel and less than 1 year for the American eel.

Bonhommeau et al. (2009a) simulated the drift of particles released in the Sargasso Sea and calculated the minimum time required for eel larvae to achieve their migration. The aim was to evaluate the minimum bound constrained by physical oceanography to passively drift (at fixed depth with no active behaviour) from the Sargasso Sea to the $20^{\circ} \mathrm{W}$ meridian (Fig. 1). Their results showed that the migration up to the $20^{\circ} \mathrm{W}$ meridian, i.e., $1000-1500 \mathrm{~km}$ from the European shelves, requires at least 10 months and 19 days covering 8,447 km (Fig. 1). This is the shortest migration duration achieved by the fastest particle among several million released in the Sargasso Sea. It enabled the authors to conclude that a duration of migration less than 1 year is highly unlikely for a significant part of the particles. It is worth noting that this estimation clearly underestimated the complete duration of migration as the finishing line is still far from the European shelves and metamorphosis has not yet begun.

Last, using Lagrangian simulations accounting for mortality of leptocephali, Bonhommeau et al. (2009b) estimated that the mean duration of migration of European eel leptocephali is 21 
months and that less than $0.2 \%$ of eel larvae may typically survive the trans-Atlantic migration.

In summary, simulations of the oceanic migration of eel larvae using general ocean circulation models showed the strong potential of these approaches to unravel migration pathways. This approach appears to invalidate a duration of migration of less than 1 year for American eels and less that 1.5 year for European eels.

\subsubsection{Possible sources of misinterpretation}

The study of Kettle and Haines (2006) using Lagrangian simulations to model the migration of European eel larvae provided for the first time an estimate of the migration routes and duration under a purely passive drift hypothesis. Circulation models provide good estimates of the global circulation patterns at the North Atlantic scale in terms of mean speed and position of currents (Smith et al. 2000). However, the accuracy and the degree of realism of studies based on ocean general circulation models can be questioned. Several criticisms have been raised regarding the accuracy of the simulation results that may oversimplify larval trajectories.

First, simulation results may be sensitive to the resolution of ocean general circulation models. Depending on the resolution, ocean general circulation models can be classified into two groups: "eddy-permitting" models which have a horizontal resolution up to $1 / 4^{\circ}$ and employ a mesh of about $25 \mathrm{~km}$ as used by Kettle and Haines (2006) and "eddy-resolving" models which have a higher horizontal resolution of up to $1 / 15^{\circ}$ and use a mesh of $5-7 \mathrm{~km}$. The resolution has consequences for the ability to represent the meso- and submeso-scale eddies. The higher the resolution in the model, the higher the maximal speed and this allows the representation of "lower-scale" currents such as the Azores Current (Smith et al. 2000). The choice of the ocean general circulation models may therefore have a great impact on routes and durations of the modelled eel larval migration. Further studies have to be carried out to investigate the influence of the use of higher resolution models on the migration duration.

Second, ocean general circulation models differ in the way they take advantage of available in situ observations. Some are assimilating in situ or satellite-derived data as used by Kettle and Haines (2006) and others are only "fully prognostic" models that do not use assimilated ocean data. Roughly speaking, the assimilation of data "forces" the model to fit with observations and may thus provide a better representation of ocean reality. For two ocean global circulation models having the same resolution, the assimilation of data improves particularly the representation of "lower-scale" currents and slightly increases the mean and maximum current speed estimated by the model (Bonhommeau et al. 2009a).

To conclude, even though Lagrangian modelling needs improvements some of which we have suggested above, the reliability of ocean global circulation models to estimate passive drift is now well accepted (Smith et al. 2000). Yet, biological processes may change predictions of migration duration stemming from global oceanic circulation models. These questions are further examined in the next section.

\section{Assessing the different estimations in the light of the knowledge about physiology, ecology and physical oceanography}

The literature reviewed in previous sections points out that estimates of the duration of migration depend on the method which is used, especially for the European eel. In situ larval sampling, otolith macrostructure, and ocean circulation models assuming a passive drift estimate a long duration of migration lasting for 2 years or more for the European eel and for 1 year for the American eel. By contrast, otolith microstructure analyses estimate a short duration of migration that lasts for 1 year in both species (Figs. 2 and 3) or even 7 months 
(Lecomte-Finiger 1992, 1994a). Yet none of the methods have been really validated. In the previous section, the methodological caveats of each method were examined, thus providing insight into the degree of confidence one can attribute to the different results. In this section, we further discuss the controversy around the migration duration and compare results with what is known about the physiology and ecology of eels and the physical oceanography.

\subsection{Consistency of the duration of migration with the physiology and ecology}

\section{of Atlantic eels}

\subsubsection{Hatching and arrivals dates}

The debate on the validity of interpretation of otolith microstucture raised by the inherent growth properties of otoliths is completed by the inconsistencies between back-calculated hatching dates of eel larvae and the observed spawning season. McCleave (2008) emphasized the mismatch between the sampling of newly hatched leptocephali from March to May for the European eel and in February-March for the American eel, and the backcalculated spawning season estimated to be year-round from different otolith microstructure studies. For instance, the back-calculated hatching dates of the glass eels sampled in Lecomte-Finiger (1992) and Désaunay et al. (1996) are comprised between April to December. However, after August, no leptocephalus smaller than $10 \mathrm{~mm}$ has ever been caught in the Sargasso Sea. The spawning season concentrated from March to May for the European eel larvae and the main arrival season of glass eels between December and February for the Bay of Biscay implies a duration of migration between 10 and 12 months or modulo 10-12 months. We refer to McCleave (2008) for an in-depth review of the contrast between spawning times of eels and back-calculated ages of eel larvae.

\subsubsection{An active and oriented swimming for eel larvae?}

An active and oriented horizontal swimming activity could also be invoked as a factor to accelerate the migration duration. Apart from vertical swimming, horizontal swimming by leptocephali has also been observed in the laboratory (e.g., Bishop and Torres 1999; Wuenschel and Able 2008). However, Bonhommeau et al. (2009a) pointed out that even though leptocephali have a swimming ability, the swimming speed required to cross the Atlantic in 6 months would be at least $24 \mathrm{~cm} \cdot \mathrm{s}^{-1}$, which is more than 3 body lengths per second required for a fully developed leptocephalus $(70 \mathrm{~mm})$, or 6 body lengths per second for an average sized leptocephalus of $35 \mathrm{~mm}$, keeping in mind that such speed estimates assume perfect orientation. Although such absolute swimming speeds are observed for migrating adult fish (Blaxter 1969), sustaining such oriented high-speed swimming during the whole duration of migration on the part of fish larvae appears rather unrealistic. Moreover, Wuenschel and Able (2008) estimated that American glass eels and leptocephali of the Conger eel (Conger oceanicus) can sustain swimming speeds of $6.5-9.5 \mathrm{~cm} \mathrm{~s}^{-1}$, or about 1 to 1.5 body lengths per second. Yamada et al. (2009) observed reared leptocephali of the Japanese eel in captivity and measured a $3.6 \mathrm{~cm} \mathrm{~s}^{-1}$ swimming speed ( 0.69 body length per second). This range remains well below the swimming speed required to render the short duration of migration of the European eel larvae consistent with oceanic circulation models. In the following section, we develop arguments to explain why there are serious doubts about the ability of European eels to sustain the fast oriented swimming over several months that would be required to account for a short duration of migration. 


\section{An oriented swimming}

Some fish larvae possess the ability to orient in the ocean to perform small-scale migrations (tens of $\mathrm{km}$ ), but larval orientation has not been observed at the scale that would be required for oriented swimming by Atlantic Anguilla (thousands of $\mathrm{km}$ ). Leis (2006) published a literature review entitled "Are larvae of demersal fishes plankton or nekton"? The simple answer is that such larvae are both plankton and nekton. During the early larval stage, larvae are closer to the simplified "passive drift with currents" assumption, although they perform diel vertical migrations that indirectly influence their dispersal. As larvae develop, the passive assumption becomes invalid. Larvae are capable of swimming faster than mean ambient currents for long periods, travelling tens of kilometres. Most of the literature on larval fish behaviour comes from reef ecosystems (e.g., Leis and Carson-Ewart 2003; Leis 2007; Paris et al. 2007), where larvae have been reported to perform oriented movements as large as tens of km using mostly reef noise or the sun as cues for orientation. Ramzi et al. (2001) and Fox et al. (2006) showed how active swimming in flatfish larvae influences the ability to reach their nursery area and increase settlement success and the dependent recruitment.

Hence, if some fish larvae have been found to exhibit active oriented swimming behaviour, larvae have never been reported to perform large-scale (thousands of $\mathrm{km}$ ) active oriented migrations and no studies have been conducted on the orientation of leptocephali.

\section{Energetic expenditures and muscles needed to swim fast and long enough}

From the former argumentation, the orientated migration towards Europe remains conjectural (McCleave et al. 1998). Thus, one remaining question relies upon the ability of eel larvae to swim over several thousands of $\mathrm{km}$ to achieve their migration, and to swim fast enough to reach the European coasts in less than 1 year. Such active swimming would require developed muscles. Eel leptocephali have a willow leaf shape that enables them to use currents for drifting. However, they do not seem able to sustain a long and active swimming activity, which requires developed muscles. Leonard and Summers (1976) reported that leptocephali have only minute amounts of subcutaneous red muscle (McCleave et al. 1998). This active migration would also require substantial food availability to cover energetic expenditures. The open ocean is a low productive area (Raven et al. 2007), and leptocephalus nutrition remains poorly understood even though discarded larvacean houses and zooplankton fecal pellets have been identified in guts (Otake et al. 1993; Mochiaka and Iwamizu 1996; Pfeiler 1999). The energy expenditure required to maintain such an active swimming of eel larvae during a long migration seems unrealistic.

\subsection{Consistency of the duration of migration with the physical oceanography}

Coupled to particle tracking model, physical models of ocean circulation provide a reliable and validated tool to study the migration of fish larvae (Smith et al. 2000, Cowen et al. 2000). Applied to Atlantic eel larvae, this modelling approach suggests a long duration of migration for the European eel. A fundamental issue which may determine the accuracy of particle drift simulations is the nature of eel larval behaviour during the drift. As discussed above, an active and oriented migration of leptocephali has been proposed to explain these discrepancies (Lecomte-Finiger 1992; Cheng and Tzeng 1996; Wang and Tzeng 2000). Moreover, implementing natural mortality in Lagrangian simulations may also change the estimates of the migration duration (Cowen et al. 2000). In this section, we review the most recent results derived from Lagrangian simulations and we examine whether natural mortality and realistic active particle behaviour could bring closer predictions from oceanic circulation models and analysis of otolith microstructure. 


\subsubsection{Influence of active behaviours}

Bonhommeau et al. (2009a) showed that the shortest migration duration of particles drifting passively and at fixed-depth from the Sargasso Sea to the $20^{\circ} \mathrm{W}$ meridian is at least 10 months and 19 days. Because eel larvae are known to perform diel vertical migrations (Castonguay and McCleave 1987), Bonhommeau et al. (2009a) completed their analysis by implementing an active vertical diel migration between $300 \mathrm{~m}$ (daytime) and $50 \mathrm{~m}$ (at night). Their results showed that such a realistic active behaviour of eel larvae does not accelerate their migration across the Atlantic Ocean. On the contrary, the estimates of the duration of migration and the distance covered increased. The fastest particle travelled in 1 year and 3 months and covered $9700 \mathrm{~km}$, that is 5 months and $1300 \mathrm{~km}$ longer than a theoretical passive migration at fixed-depth. Hence it does not seem that vertical migration can explain a shorter migration of European eel larvae.

Bonhommeau et al. (2009a) also assessed the potential impact of a putative oriented drift where particles were able to select the depth where the current velocity was the highest. This theoretical behaviour resulted in an increase in the duration of migration compared with the fixed-depth hypothesis (1 year and 1 month and $9200 \mathrm{~km}$ for the fastest particle of this experiment). In conclusion, the active behaviours tested in Bonhommeau et al. (2009a) do not reconcile predictions from oceanic circulation models and analysis of otolith microstructure.

\subsubsection{Influence of natural mortality}

Accounting for fish larval mortality in Lagrangian studies revealed to be critical for successfully applying this modelling approach (Cowen et al. 2000, Leis 2007, Bonhommeau et al. 2009b). Kettle and Haines (2006) did not implement a realistic mortality hypothesis to estimate the duration of migration of European eel larvae. In their simulations, the particles were followed over 2 years, implicitly considering a $0 \%$ mortality over the first 2 years and $100 \%$ mortality after 2 years of drift. Yet, accounting for the mortality of particles in Lagrangian simulations to mimic natural mortality of eel larvae necessarily leads to a decrease in estimates of the mean migration duration: without mortality, even the slowest particles eventually succeed in reaching the European shelves, and the mean migration duration is larger when natural mortality is implemented. A first progress in this direction was proposed by Bonhommeau et al. (2009b) who developed a method to estimate the natural mortality of eel larvae and account for it in their lagrangian simulations. They estimated a mean duration of migration to be 21 months for European eel larvae. This result revealed not sensitive to the type of behaviour tested (drift at fixed-depth, vertical diurnal migration or fastest current choice). Accounting for larval mortality hence provided a more realistic description of the migration of eel larvae and supported a long duration of migration for European eel larvae.

\section{Conclusion}

The extensive literature on Atlantic Anguilla larvae reviewed in this paper highlighted that some of the main features of the oceanic stage are now well established. The spawning season occurs from February to April for the American eel and March to June for the European eel. The spawning area is located in the Sargasso Sea, and adult eels may choose physical features such as temperature fronts to determine the spawning location.

By contrast, much more discrepancies in the literature arise when looking at the duration of migration. The different approaches (size structure, otolith macro and microstructure, passive drift estimated from ocean models) all agree to estimate a duration of migration of 6 months for the Japanese eel. A moderate discrepancy arises with the American eel, for which 
microstructure results indicate a migration duration several months (about a third) shorter than the size structure or circulation model methods. The discrepancy then becomes really large in the European eel, as the different methods lead to durations ranging from 7-9 months, estimated from otolith microstructure studies, to more than 2 years, estimated from studies using cohort analyses, otolith macrostructure, and numerical modelling (Fig. 2). Finally, our review points out that the methods inferring a long migration are more robust to methodological caveats than those estimating short durations of migration.

Global ocean circulation models are validated (Smith et al., 2000) and allow the estimation of a passive drift using particle tracking models. Yet, a fundamental issue that determines the accuracy of simulations of particle drift is the nature of the behaviour of eel larvae during their oceanic migration. Results of these modelling approaches are however consistent with a long duration of migration (more than 1.5 years) for the European eel. Ocean circulation alone cannot account for a short duration of migration for the European eel larvae. Hence, results of otolith microstructure analyses imply an oriented and active swimming. In light of the existing knowledge, several aspects make us express reservations about the hypothesis of an active and oriented swimming ability allowing eel larvae to cross the Atlantic Ocean in less than 1 year: (i) fish larvae have never been reported to perform large-scale active oriented migrations, (ii) the required speed would be unrealistically high (6 body length per second for a $35 \mathrm{~mm}$ leptocephalus assuming perfect orientation), (iii) eel larvae do not possess the red muscles needed to sustain such a swimming speed and the energetic expenditures could hardly be covered given what is known about the diet of eel larvae and the poor ocean productivity in the tropical Atlantic.

A validation of growth increment formation in otoliths of Atlantic Anguilla leptocephali has to be carried out. This mainly concerns the potential problem of daily increments being formed but below the resolution limit of microscopy due to slow growth rates (Campana et al. 1987).

Even though a short duration of migration for the European eel larvae appears less credible than a long one, it cannot be completely refuted in light of the reviewed literature. Several research avenues may be followed to unravel the question of the duration of migration. Field studies and sampling efforts are needed to improve our knowledge of migration routes and duration and could give support to modelling approaches. Otolith microchemistry may be a useful tool to investigate the temperature history of leptocephali (e.g., de Casamajor et al. 2002). The use of particle tracking models seems to be a promising approach since it enables scientists to work not only on the duration of migration but on possible routes and specific spawning locations, and to test possible swimming speeds required to cross the Atlantic. Another promising method relies on artificial reproduction, which has just been accomplished at the National Institute of Aquatic Resources of Denmark by producing viable eggs and reared larvae of captive European eel for up to 12 days (http://www.dfu.dtu.dk). Furthermore, first production of glass eels in captivity was recently accomplished in the Japanese eel (Tanaka et al. 2003). It would therefore be possible to assess whether daily increments in otoliths could be confirmed on reared leptocephali. Reared larvae may also be used to study swimming energetics.

\section{Acknowledgements}

We thank Dr. S.E. Campana for sharing information and providing advice on otolith microstructure and Ms. Laure Devine for improving an earlier draft. The expertise of the Fisheries and Aquatic Sciences Center of AGROCAMPUS OUEST in eel ecology made the literature search much easier. We thank them for providing us with these old (and dusty) papers and books. S.B. thanks C. Briand for his help in the conception of the figure. 


\section{References}

Albert, Prince de Monaco. (1932) A new chart of the currents of the North Atlantic (Read at meeting of British Association, 1892). Résultats des Campagnes Scientifiques du Prince Albert 1 84, 132-135.

Anonymous (2003) Worldwide decline of eel resources necessitates immediate action Québec declaration of concern. Fisheries 28, 28-30.

Antunes, C. and Tesch, F-.W. (1997) A critical consideration of the metamorphosis zone when identifying daily rings in otoliths of European eel, Anguilla anguilla (L). Ecology of Freshwater Fish 6, 102-107.

Arai, T., Otake, T. and Tsukamoto, K. (2000) Timing of metamorphosis and larval segregation of the Atlantic eels Anguilla rostrata and $A$. anguilla, as revealed by otolith microstructure and microchemistry. Marine Biology 137, 39-45.

Behrenfeld, M.J., O'Malley, R.T., Siegel, D.A., et al. (2006) Climate-driven trends in contemporary ocean productivity. Nature 444, 752-755.

Berg, R. (1985) Age determination of eels, Anguilla anguilla L.: comparison of field data with otolith ring patterns. Journal of Fish Biology 26, 537-544.

Bergstad, O.A. (1984) A relationship between the number of growth increments on the otoliths and age of larval and juvenile cod, Gadus morhua. Flød Rapport 1, 251-272.

Bishop, R.E. and Torres, J.J. (1999) Leptocephalus energetics: Metabolism and excretion. Journal of Experimental Biology 202, 2485-2493.

Boëtius, J. and Harding, E.F. (1985) A re-examination of Johannes Schmidt's Atlantic eel investigations. Dana 4, 129-162.

Bonhommeau, S., Chassot, E. and Rivot, E. (2008a) Fluctuations in European eel (Anguilla anguilla) recruitment resulting from environmental changes in the Sargasso Sea. Fisheries Oceanography 17, 32-44.

Bonhommeau, S., Chassot, E., Planque, B., Rivot, E., Knap, A.H. and Le Pape, O. (2008b) Impact of climate on eel population of the Northern Hemisphere. Marine Ecology Progress Series 373, 71-80.

Bonhommeau, S., Blanke, B., Tréguier, A.-M., Grima, N., Rivot, E., Vermard, Y., Greiner, E. and Le Pape, O. (2009a) How fast can the European eel larvae cross the Atlantic Ocean? Fisheries Oceanography. doi:10.1111/j.1365-2419.2009.00517x

Bonhommeau, S., Le Pape, O., Gascuel, D., Blanke, B., Tréguier, A.-M., Grima, N., Vermard, Y., Castonguay, M. and Rivot, E. (2009b) Estimates of the mortality and the duration of the trans-Atlantic migration of European eel leptocephali using a particle tracking model. Journal of Fish Biology 74, 1891-1914. doi:10.1111/j.1095-8649.2009.02298.x.

Blaxter, J.H.S. (1969). Swimming speed of fish. FAO Technical. report, Fisheries Report 62, 69-100.

Campana, S.E. (1984) Microstructural growth patterns in the otoliths of larval and juvenile starry flounder, Platichthys stellatus. Canadian Journal of Zoology 62, 1507-1512.

Campana, S.E. and Neilson, J.D. (1985) Microstructure of fish otoliths. Canadian Journal of Fisheries and Aquatic Sciences 42, 1014-1032.

Campana, S.E., Gagné, J.A. and Munro, J. (1987) Otolith microstructure of larval herring (Clupea harengus): Image or reality? Canadian Journal of Fisheries and Aquatic Sciences 44, 1922-1929.

de Casamajor, M.N., Lecomte-Finiger, R., Blamart, D., Cagnon, C. and Prouzet, P. (2002) Etude du passe larvaire transatlantique de la civelle (Anguilla anguilla) dans le Golfe de Gascogne. Premier Colloque du défi Golfe de Gascogne. Session 2: Comprendre les interactions entre la dynamique des structures physiques et la dynamique biologique dans le golfe de Gascogne. Available at http://www.ifremer.fr/gascogne/actualite/colloque/poster/de\%20casamajor.doc.

Casselman, J.M. (1982) Chemical analyses of the optically different zones in eel otoliths. Ontario Fisheries Technical Report Series 4, 74-82. 
Castonguay, M. (1987) Growth of American and European eel leptocephali as revealed by otolith microstructure. Canadian Journal of Zoology 65, 875-878.

Castonguay, M. and McCleave, J.D. (1987) Vertical distributions, diel and ontogenic vertical migrations and net avoidance of leptocephali of Anguilla and other common species in the Sargasso Sea. Journal of Plankton Research 9, 195-214.

Cheng, P.W. and Tzeng, W.N. (1996) Timing of metamorphosis and estuarine arrival across the dispersal range of the Japanese eel Anguilla japonica. Marine Ecology Progress Series 131, 87-96.

Cieri, M.D. (1999) Migrations, growth and early life history of the American eel (Anguilla rostrata). Ph.D. Thesis, University of Maine.

Cieri, M.D. and McCleave, J.D. (2000) Discrepancies between otoliths of larvae and juveniles of the American eel: is something fishy happening at metamorphosis? Journal of Fish Biology 57, 1189-1198.

Cieri, M.D. and McCleave, J.D. (2001) Validation of daily otolith increments in glass-phase American eels Anguilla rostrata (Lesueur) during estuarine residency. Journal of Experimental Marine Biology and Ecology 257, 219-227.

CITES (2007) Notification to the Parties, No 2007/022, Geneva, 26 July, 2007. www.cites.org/common/cop/14/inf/E14i-21.pdf

Correia, A.T., Antunes, C. and Coimbra, J. (2002) Aspects of the early life history of the European conger eel (Conger conger) inferred from the otolith microstructure of metamorphic larvae. Marine Biology 140, 165-173.

Correia, A.T., Able, K.W., Antunes, C. and Coimbra, J. (2004) Early life history of the American conger eel (Conger oceanicus) as revealed by otolith microstructure and microchemistry of metamorphosing leptocephali. Marine Biology 145, 477-488.

Correia, A.T., Antunes, C., Wilson, J.M. and Coimbra, J. (2006) An evaluation of the otolith characteristics of Conger conger during metamorphosis. Journal of Fish Biology 68, 99-119.

Cowen, R.K., Lwiza, K.M.M., Sponaugle, S., Paris, C.B. and Olson, D.B. (2000). Connectivity of marine populations: Open or closed? Science 287, 857-859.

Dahl, J. (1967) Some recent observations on the age and growth of eels. (Proceedings of the 3rd British Course Fish Conference, Liverpool, University of Liverpool, 1967).

Deelder, C.L. (1976) The problem of the supernumary zones in otoliths of the European eel (Anguilla vulgaris (Linneaus, 1758)); suggestion to cope with it. Aquaculture 9, 373-379.

Deelder, C.L. (1981) On the age and growth of cultured eels, Anguilla anguilla (Linnaeus, 1758). Aquaculture 26, 13-22.

Deelder, C.L. and Tucker, D.W. (1960) The Atlantic eel problem. Nature 185, 589-592.

Dekker, W. (1987) Further studies on age reading of European eel using tetracycline labeled otoliths. (Proceedings of the EIFAC, Working Party on Eels, Bristol, 1987).

Désaunay, Y., Lecomte-Finiger, R. and Guérault, D. (1993) Mean age migration patterns of Anguilla anguilla (L.) glass eels from three French estuaries (Somme, Vilaine and Adour rivers). Report of the eighth session of the Working Party on Eel, Olstyn, Poland.

Désaunay, Y., Guérault, D. and Lecomte-Finiger, R. (1996a) Variation of the oceanic larval migration of Anguilla anguilla (L.) glass eels from a two year study in the Vilaine Estuary (France). Archives of Polish Fisheries 4, 195-210.

Désaunay, Y., Lecomte-Finiger, R. and Guérault, D. (1996b) Mean age and migration patterns of Anguilla anguilla (L.) glass eels from three French estuaries (Somme, Vilaine and Adour rivers). Archives of Polish Fisheries 4, 187-194.

Fox, C.J., McCloghrie, P., Young E.F. and Nash, R.D.M. (2006) The importance of individual behaviour for successful settlement of juvenile plaice (Pleuronectes platessa L.): a modelling and field study in the eastern Irish Sea. Fisheries Oceanography 15, 301-313.

Friedland, K.D., Miller, M.J. and Knights, B. (2007) Oceanic changes in the Sargasso Sea and declines in recruitment of the European eel. ICES Journal of Marine Science 64, 519530.

Fukuda, N., Kuroki, M., Shinoda, A., Yamada, Y., Okamura, A., Aoyama, J. and Tsukamoto, K. (2009) Influence of water temperature and feeding regime on otolith growth in Anguilla 
japonica glass eels and elvers: does otolith growth cease at low temperature? Journal of Fish Biology 74 doi:10.1111/j.1095-8649.2009.02287.x.

Furuya, K., Odate, T. and Tagushi, K. (1995) Effects of a seamount on phytoplankton production in the western Pacific Ocean. In: Biogeochemical Processes and Ocean Flux in the Western Pacific. (Eds. H. Sakai, Y. Nozaki), Terra Scientific Publishing Company (TerraPub), Tokyo, pp. 255-273.

Geffen, A.J. (1982) Otolith ring deposition in relation to growth rate in herring (Clupea harengus) and turbot (Scophtalmus maximus) larvae. Marine Biology 71, 317-326.

Geffen, A.J. (1992) Validation of otolith increment deposition rate. In: Otolith microstructure examination and analysis. (Eds. D.K. Stevenson, S.E. Campana), Canadian Special Publication of Fisheries and Aquatic Sciences 117, pp. 101-113.

van Ginneken, V.J.T. and Maes, G.E. (2005) The European eel (Anguilla anguilla, Linnaeus), its lifecycle, evolution and reproduction: a literature review. Reviews in Fish Biology and Fisheries 15, 367-398.

Grassi, G.B. (1896) The reproduction and metamorphosis of the common eel (Anguilla vulgaris). Proceedings of the Royal Society of London 60, 260-271.

Harden Jones, F.R. (1968) The eel. In: Fish Migration, London: Edward Arnold, pp. 69-85.

Hermann, F. and Thomsen, H. (1946) Drift-bottle experiments in the northern North Atlantic. Meddelelser fra Kommissionen for Danmarks Fiskeri-Og Havunder Soegelser. Serie: Hydrografi 3(4).

Hjort, J. (1914) Fluctuations in the great fisheries of northern Europe. Rapport des Procèsverbaux du Conseil international pour l'Exploration de la Mer 20, 1-228.

Hulet, W.H. and Robins, R. (1989) The evolutionary significance of the leptocephalus larva. In: Fishes of the western North Atlantic. Part. 9 Vol. 2. (Ed. E.A. Böhlke), Sears Foundation for Marine Research, New Haven, USA, pp. 669-679.

ICES (2009). Workshop on age reading of European and American eel (WKAREA), 20-24 April 2009, Bordeaux, France. ICES CM 2009IACOM: 48. 66 pp.

Jansen, S. (1991) Mikrostructuruntersuchungen an Otolithen des Europaischen Aales Anguilla anguilla (Linnaeus, 1758). Diplomarbeit, Fachbereich Biologie, Universitat Hamburg, 65 pages.

Kaup, J.J. (1856) Catalogue of apodal fish in the collection of the British Museum, London. (Proceedings of the Trustees of the British Museum, London, 1856).

Kettle, A.J. and Haines, K. (2006) How does the European eel (Anguilla anguilla) retain its population structure during its larval migration across the North Atlantic Ocean? Canadian Journal of Fisheries and Aquatic Sciences 63, 90-106.

Kim, H., Kimura, S., Shinoda, A., Kitagawa, T., Sasai, Y. and Sasaki, H. (2007) Effect of El Nino on migration and larval transport of the Japanese eel (Anguilla japonica). ICES Journal of Marine Science 64, 1387-1395.

Kimura, S., Doos, K. and Coward, A.C. (1999) Numerical simulation to resolve the issue of downstream migration of the Japanese eel. Marine Ecology Progress Series 186, 303-306.

Kleckner, R.C. and McCleave, J.D. (1985) Spatial and temporal distribution of American eel larvae in relation to North Atlantic Ocean current systems. Dana 4, 67-92.

Kleckner, R.C. and McCleave, J.D. (1988) The northern limit of spawning by Atlantic eels (Anguilla spp.) in the Sargasso Sea in relation to thermal fronts and surface water masses. Journal of Marine Research 46, 647-667.

Knights, B. (2003) A review of the possible impacts of long-term oceanic and climate changes and fishing mortality on recruitment of anguillid eels of the Northern Hemisphere. Science of the Total Environment 310, 237-244.

Kuroki, M., Aoyama, J., Miller, M.J., Wouthuyzen, S., Arai, T. and Tsukamoto, K. (2006) Contrasting patterns of growth and migration of tropical anguillid leptocephali in the western Pacific and Indonesian Seas. Marine Ecology Progress Series 309, 233-246.

Laroche, J.L., Richardson, S.L. and Rosenberg, A.A. (1982) Age and growth of a pleuronectid, Parophrys vetulus, during the pelagic larval period in Oregon coastal waters. Fishery Bulletin U.S. 80, 93-104. 
Lecomte-Finiger, R. (1992) Growth history and age at recruitment of European glass eels (Anguilla anguilla) as revealed by otolith microstructure. Marine Biology 114, 205-210.

Lecomte-Finiger, R. (1994a) The early-life of the European eel. Nature 370, 424.

Lecomte-Finiger, R. (1994b) Contribution de l'otolithométrie à l'étude de la dynamique de migration larvaire de l'anguille européenne Anguilla anguilla. Bulletin Français De La Pêche et de La Pisciculture 335, 17-31.

Lecomte-Finiger, R. (2003) The genus Anguilla Schrank, 1798: current state of knowledge and questions. Reviews in Fish Biology and Fisheries 13, 265-279.

Lecomte-Finiger, R. and Yahyaoui, A. (1989) Otolith microstructure analysis in the study of the early life history of the European eel Anguilla anguilla. (Proceedings of the EIFAC, Working Party on Eels, Porto, 1989).

Lecomte-Finiger, R., Désaunay, Y., Guérault, D. and Grellier, P. (1993) The immigration of Anguilla anguilla (L.) glass eels in coastal waters: question about the determinism of the otolith structure. Report of the eight session of the Working Party on Eel, Olstyn, Poland.

Leis, J.M. (2006) Are larvae of demersal fishes plankton or nekton? Advances in Marine Biology 51, 59-141.

Leis, J.M. (2007) Behaviour as input for modelling dispersal of fish larvae: behaviour, biogeography, hydrodynamics, ontogeny, physiology and phylogeny meet hydrography. Marine Ecology Progress Series 347, 185-193.

Leis, J.M., and Carson-Ewart, B.M. (2003) Orientation of pelagic larvae of coral reef fishes in the ocean. Marine Ecology Progress Series 252, 239-253.

Leonard, J.B. and Summers, R.G. (1976) The ultrastructure of the integument of the American eel, Anguilla rostrata. Cell and Tissue Research 171, 1-30.

Liew, P.K.L. (1974) Age determination of American eels based on the structure of their otoliths. In: Ageing of fish. (Ed. T.B. Bagenal), Unwin Brothers Limited, Surrey, pp. 124-136. Martin, M.H. (1995) Validation of daily growth increments in otoliths of Anguilla rostrata (Lesueur) elvers. Canadian Journal of Zoology 73, 208-211.

McCleave, J.D. (2008) Contrasts between spawning times of Anguilla species estimated from larval sampling at sea and from otolith analysis of recruiting glass eels. Marine Biology 155, 249-262.

McCleave, J.D. and Kleckner, R.C. (1987) Distribution of leptocephali of the catadromous Anguilla species in the western Sargasso Sea in relation to water circulation and migration. Bulletin of Marine Science 41, 789-806.

McCleave, J.D., Kleckner, R.C. and Castonguay, M. (1987) Reproductive sympatry of American and European eels and implications for migration and taxonomy. American Fisheries Society Symposium 1, 286-297.

McCleave, J.D., Brickley, P.J., O'Brien, K.M. et al. (1998) Do leptocephali of the European eel swim to reach continental waters? Status of the question. Journal of the Marine Biological Association of the United Kingdom 78, 285-306.

McGurk, M.D. (1984) Ring deposition in the otoliths of larval Pacific herring, Clupea harengus pallasi. Fishery Bulletin U.S. 82, 113-120.

Methot, R.D. and Kramer, D. Jr. (1979) Growth of northern anchovy, Engraulis mordax, and north lampfish, Stenobrachius leucopsarus. Rapport des Procès-verbaux du Conseil international pour l'Exploration de la Mer 178, 424-431.

Michaud, M., Dutil, J.D. and Dodson, J.J. (1988) Determination of the age of young American eels, Anguilla rostrata, in fresh water, based on otolith surface area and microstructure. Journal of Fish Biology 32, 179-189.

Mochioka, N. and Iwamizu, M. (1996) Diet of anguilloid larvae: Leptocephali feed selectively on larvacean houses and fecal pellets. Marine Biology 125, 447-452.

Moriarty, C. (1973) A technique for examining eel otoliths. Journal of Fish Biology 5, 183184.

Moriarty, C. (1983) Age determination and growth rate of eels, Anguilla anguilla (L). Journal of Fish Biology 23, 257-264.

Moriarty, C. and Steinmetz, B. (1979) On age determination of eel. Rapport des Procèsverbaux du Conseil international pour l'Exploration de la Mer 174, 70-74. 
Otake, T., Nogami, K. and Maruyama, K. (1993) Dissolved and particulate organic matter as possible food sources for eel leptocephali. Marine Ecology Progress Series 92, 27-34.

Pannella, G. (1971) Daily growth layers and periodical patterns. Science 173, 1124-1127.

Paris, C.B., Chérubin, L.M. and Cowen, R.K. (2007) Surfing, spinning, or diving from reef to reef: effects on population connectivity. Marine Ecology Progress Series 347, 285-300.

Pfeiler, E. (1999) Developmental physiology of elopomorph leptocephali. Comparative Biochemistry and Physiology A-Molecular \& Integrative Physiology 123, 113-128.

Polovina, J.J., Howell, E.A. and Abecassis, M. (2008) Ocean's least productive waters are expanding. Geophysical Research Letters 35 L03618, doi:10.1029/2007GL031745.

Pouchet, G. (1939) Une expérience sur les courants de l'Atlantique. Résultats des Campagnes Scientifiques du Prince de Monaco Albert 1 101, 115.

Power, J.H. and McCleave, J.D. (1983) Simulation of the North Atlantic Ocean drift of Anguilla leptocephali. Fishery Bulletin 81, 483-500.

Powles, P.M and Warlen, S.M. (2002) Recruitment season, size and age of young American eels (Anguilla rostrata) entering an estuary near Beaufort, North Carolina. Fishery Bulletin 100, 299-306.

Powles, P.M., Hare, J.A., Laban, E.H. and Warlen, S.M. (2006) Does eel metamorphosis cause a breakdown in the tenets of otolith applications? A case study using the speckled worm eel (Myrophis punctatus, Ophichthidae). Canadian Journal of Fisheries and Aquatic Sciences 63, 1460-1468.

Ramzi, A., Arino, O., Koutsikopoulos, C., Boussouar, A. and Lazure, P. (2001) Modelling and numerical simulations of larval migration of the sole (Solea solea (L.)) of the Bay of Biscay. Part 2: numerical simulations. Oceanologica Acta 24, 113-124.

Raven, P.H., Johnson, G.B. and Losos, J.B.S.S.R. (2007) Biology 7th edn. MacGrawHill, New-York, NY, USA

Schmidt, J. (1922) The breeding places of the eels. Philosophical Transactions of the Royal Society of London, Series B 211, 179-208.

Schmidt, J. (1923) Breeding places and migrations of the eel. Nature 111, 51-54.

Schmidt, J. (1927) Eel larvae in the Faroe-Channel. Journal du Conseil international pour l'Exploration de la Mer 2, 38-43.

Schmidt, J. (1935) Danish eel investigations during 25 years, 1905-1930, Carlsberg Foundation, Copenhagen.

Schoth, M. and Tesch, F.-W. (1983) Remarks on the vertical distribution of leptocephali in the Sargasso Sea with special reference to 0-group Anguilla larvae. ICES CM/M:7, 1983.

Smith, H.M. (1921) Some recent observations on the freshwater eel. Transactions of the American Fisheries Society 50, 297-300.

Smith, R. D., Maltrud, M. E., Bryan, F. O. and Hecht, M. W. (2000). Numerical simulation of the North Atlantic Ocean at 1/10 degrees. Journal of Physical Oceanography 30, 1532-1561.

Strubberg, A. (1923) Elvers from north and south Europe. (Report on the Danish Oceanographical Expeditions, 1908-10, to the Mediterranean and Adjacent Seas, 3(4)), 29 pp.

Svedäng, H., Wickstrom, H., Reizenstein, M., Holmgren, K. and Florenius, P. (1998) Accuracy and precision in eel age estimation, using otoliths of known and unknown age. Journal of Fish Biology 53, 456-464.

Tanaka, H., Kagawa, H., Ohta, H., Unuma, T. and Nomura, K. (2003). The first production of glass eel in captivity: fish reproductive physiology facilitates great progress in aquaculture. Fish Physiology and Biochemistry 28, 493-497.

Tesch, F.-W. (1980) Occurrence of eel Anguilla anguilla larvae west of the European continental shelf, 1971-1977. Environmental Biology of Fishes 5, 185-190.

Tesch, F.-W. (1998) Age and growth rates of North Atlantic eel larvae (Anguilla spp.), based on published length data. Helgoländer Meeresuntersuchungen 52, 75-83.

Tesch, F.-W. (2003) The eel, $3^{\text {rd }}$ edn, Blackwell Publishing.

Tesch, F.-W. and Wegner, G. (1989) The distribution of small larvae of Anguilla spp. related to hydrographic conditions 1981 between Bermuda and Puerto Rico. Proceedings of the EIFAC working party on eel, CM1988/M:23, in Porto, 1989. 
Tesch, F.-W., Kracht, R., Schoth, M., Smith, D.G. and Wegner, G. (1979) Report on the eel expedition of FRV "Anton Dohrn" and R.K. "Friedrich Heincke" to the Sargasso Sea 1979. (Proceedings of the ICES CM/ M:6, 1979).

Tesch, F.-W., Niermann, U. and Plaga, A. (1985) Eel larvae (Anguilla anguilla) development stage and stock density differences in time and space off the west coast of Europe. ICES CM/M:32, 1985.

Tsukamoto, K. (1989) Otolith daily increments in the Japanese eel. Nippon Suisan Gakkaishi 55, 1017-1021.

Tsukamoto, K. and Umezawa, A. (1988) Otolith-tagging of leptocephali with fluorescent substance, alizarin complexon. Technical Report. Ocean Research Institute, University of Tokyo, pp. 45-47.

Tsukamoto, K., Umezawa, A., Mochioka, N., Tabeta, O. and Kajihara, T. (1988) Otoliths of leptocephali. Tech. Rept. Ocean Research Institute, University of Tokyo, pp. 32-44.

Tsukamoto, K., Umezawa, A., Tabeta, O., Mochioka, N. and Kajihara, T. (1989) Age and birth date of Anguilla japonica leptocephali collected in western North Pacific in September 1986. Nippon Suisan Gakkaishi 55, 1023-1028.

Tucker, D.W. (1959) Eel migration. Nature 184, 1281-1283.

Umezawa, A. and Tsukamoto, K. (1989) Daily growth increments in the larval otolith of the Japanese eel, Anguilla japonica. Japanese Journal of Ichthyology 35, 440-444.

Umezawa, A. and Tsukamoto, K. (1991) Factors influencing otolith increment formation in Japanese eel, Anguilla japonica, elvers. Journal of Fish Biology 39, 211-223.

van Utrecht, W.L. and Holleboom, M.A. (1985) Notes on eel larvae (Anguilla anguilla Linneaeus, 1758) from the central and eastern North Atlantic and on glass eels from European continental shelf. Bijdragen tot de Dierkunde 55, 249-262.

Véró, M., Paulovits, G. and Biró, P. (1986) An improved grinding technique for examining fish otoliths for age and growth studies with special consideration of the eel, Anguilla anguilla L. Aquaculture and Fisheries Management 17, 207-212.

Vladykov, V.D. (1964) Quest for the true breeding area of the American eel (Anguilla rostrata Lesueur). Journal of the Fisheries Research Board of Canada 21, 1523-1530.

Vladykov, V.D. and March, H. (1975) Distribution of leptocephali of the two species of Anguilla in the western North Atlantic based on collections made between 1933 and 1968. Syllogeus 6, 5-35.

Vøllestad, L.A. and Næsje, T.F. (1988) Reading otoliths of eels; Anguilla anguilla L., of known age from Kolderveen, The Netherlands. Aquaculture and Fisheries Management 19, 387-391.

Vøllestad, L.A., Lecomte-Finiger, R. and Steinmetz, B. (1987) Age determination of Anguilla anguilla and related species. EIFAC Occasional Paper, 21, 1-28.

Wang, C.H. and Tzeng, W.N. (2000) The timing of metamorphosis and growth rates of American and European eel leptocephali: A mechanism of larval segregative migration. Fisheries Research 46, 191-205.

Wiedemann Smith, S. (1968) Otolith age reading by means of surface structure examination. Journal du Conseil international pour l'Exploration de la Mer 32, 270-277.

Winge, O. (1923) The Sargasso Sea, its boundaries and vegetation. Report of the Danish oceanographical Expeditions 1908-1910 3, 3-34.

Wippelhauser, G.S., McCleave, J.D. and Kleckner, R.C. (1985) Anguilla rostrata leptocephali in the Sargasso Sea during February and March 1981. Dana 4, 93-98.

Wuenschel, M.J. and Able, K.W. (2008) Swimming ability of eels (Anguilla rostrata, Conger oceanicus) at estuarine ingress: contrasting patterns of cross-shelf transport? Marine Biology 154, 775-786.

Yamada, Y., Okamura, A., Mikawa, N., Utoh, T., Horie, N., Tanaka, S., Miller, M.J. and Tsukamoto, K. (2009) Ontogenic changes in phototactic behaviour during metamorphosis of artificially reared Japanese eel Anguilla japonica larvae. Marine Ecology Progress Series $379,241-251$. 


\section{Figures}

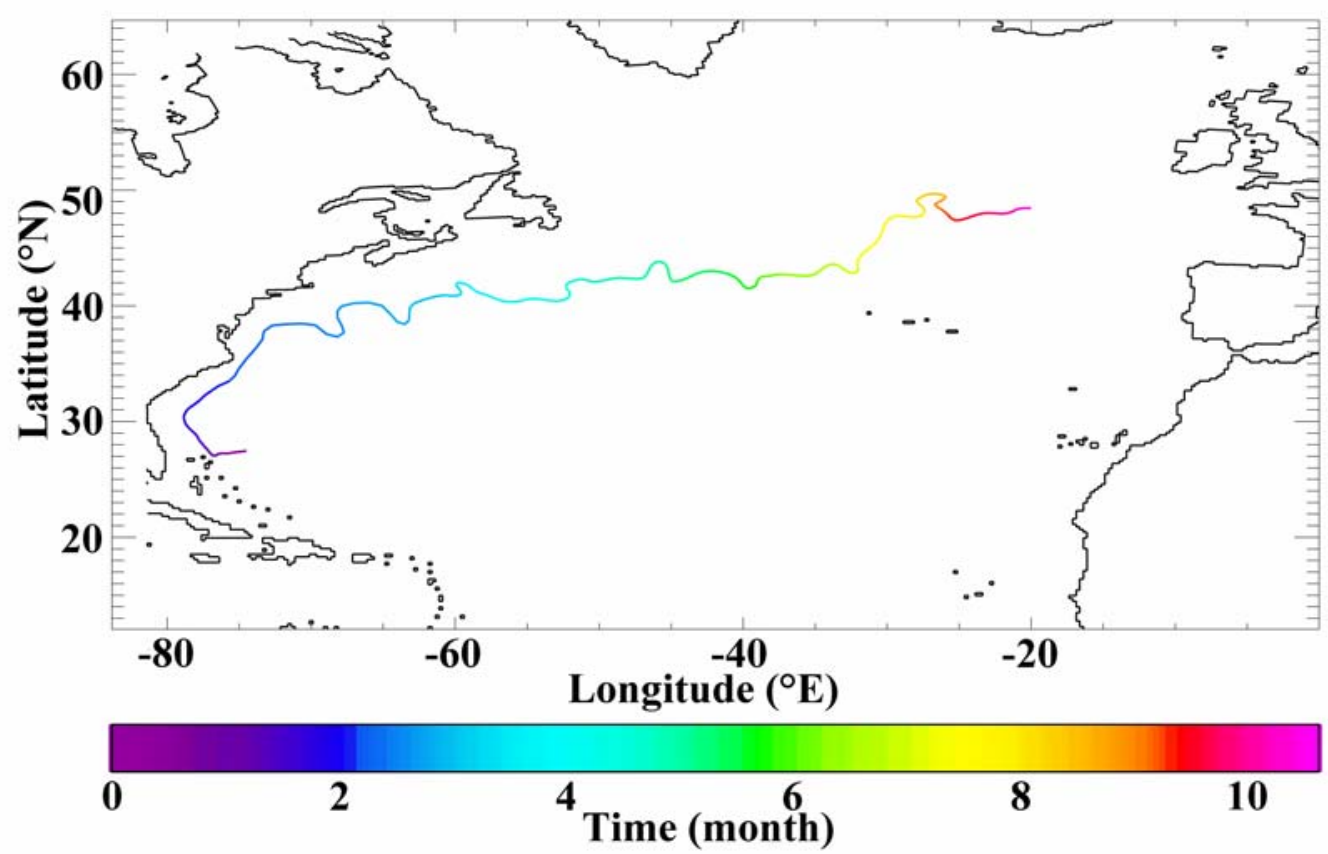

Figure 1

Figure 1: Results of Lagrangian simulations using ocean general circulation models (here the Drakkar model). Here we have charted out the trajectory of the fastest particle (defined as an European eel larva) for fixed-depth drift. Particles were stopped when they reached $20^{\circ} \mathrm{W}$, which we defined as the finishing line of our simulations. 


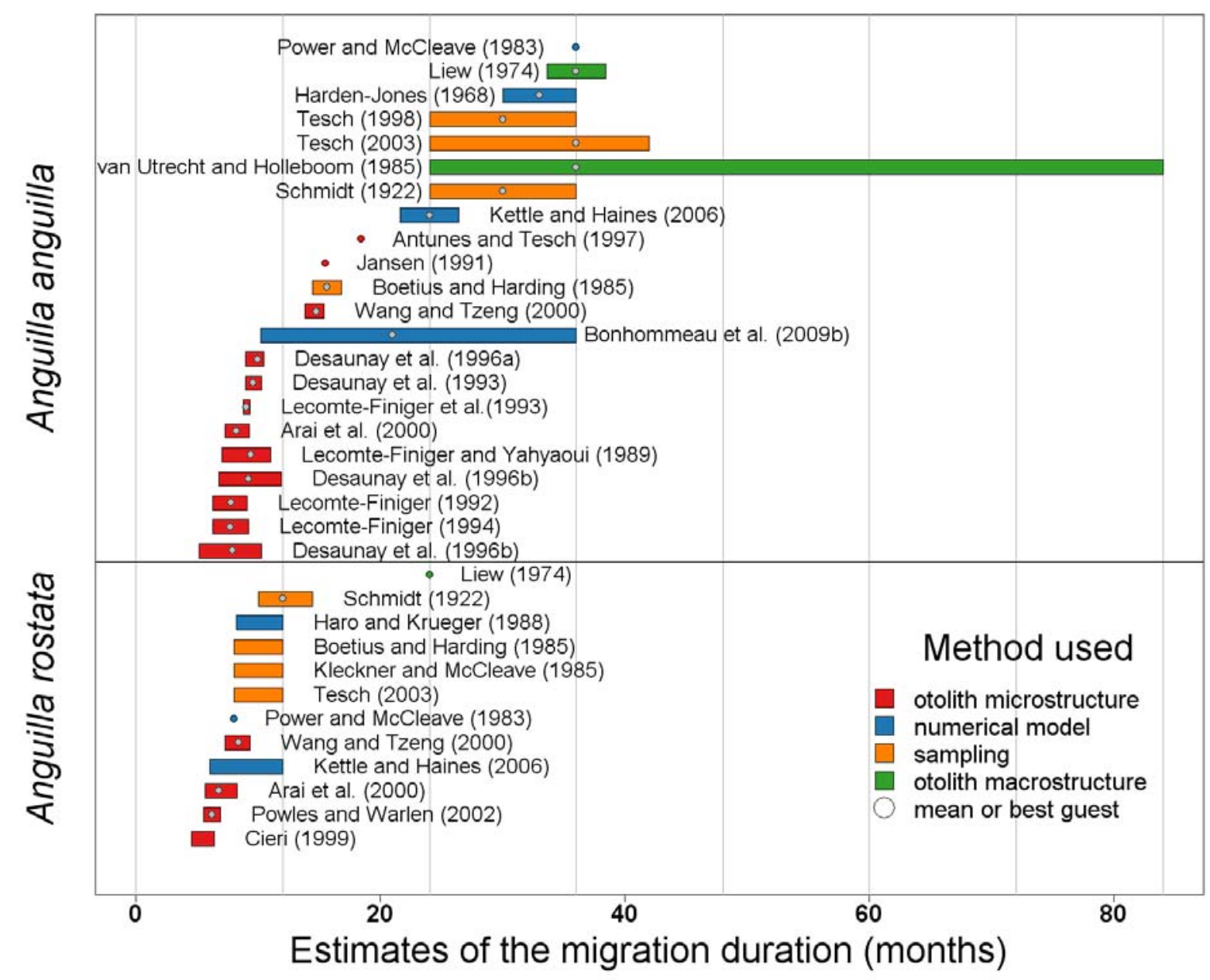

\section{Figure 2}

Figure 2: Range and mean (circle) values of the migration durations of the European ( $A$. anguilla) and American ( $A$. rostrata) eels given in the different studies. Studies are clustered by method (see colour legend). 
Figure 3

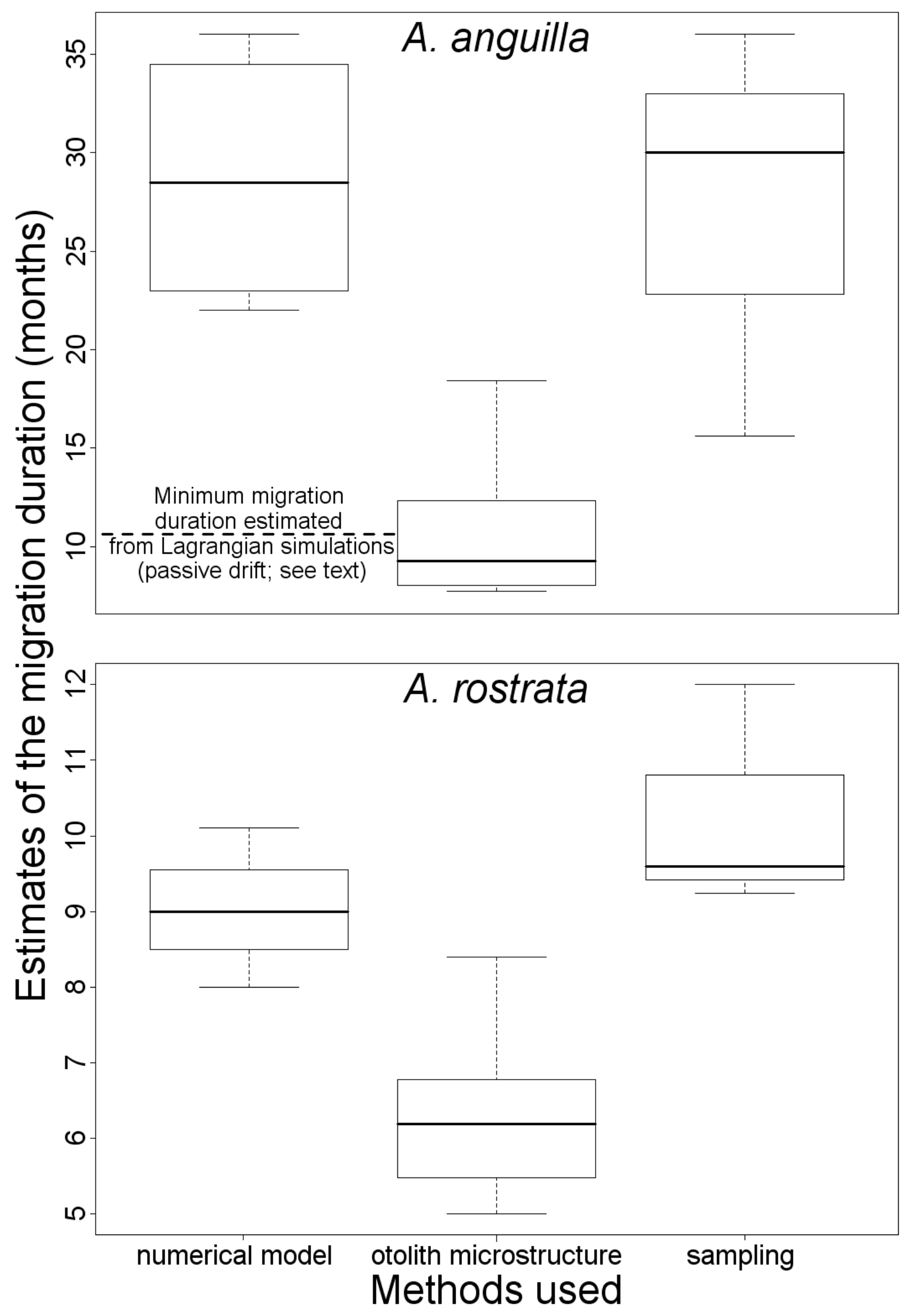


Figure 3: Boxplots of the mean migration duration estimated from three different methods (numerical models, otolith microstructure analyses, sampling studies) for the European (upper panel) and American (lower panel) eel. The data come from the different studies cited in Fig. 2. The dashed line corresponds to the minimum migration duration estimated from physical oceanography (i.e., Lagrangian simulations). 